УДК 159.9.072.43

\title{
СОСТОЯНИЕ ТРЕВОЖНОСТИ У СТУДЕНТОВ МЕДИЦИНСКИХ ВУЗОВ, РАБОТАВШИХ В «КРАСНОЙ ЗОНЕ» В ПЕРИОД ПАНДЕМИИ COVID-19
}

\author{
Магомедова Патимат Юсуповна \\ Кухмазова Зарина Мамейевна \\ Юзбекова Аида Артуровна \\ студенты
}

Научный руководитель: Абдуллаева Наида Муртазалиевна

к.б.н., доцент кафедры нормальной физиологии, руководитель отдела грантов и инноваций ФГБОУ ВО «Дагестанский государственный медицинский университет» Минздрава РФ

\begin{abstract}
Аннотация: пандемия COVID-19 оказывает неблагоприятное влияние не только на физическое, но и на психологическое здоровье населения. В статье рассмотрены результаты исследования, проведенного в апреле-июне 2020 года методом опроса студентов медицинских вузов. Выборка составила 226 человек в возрасте от 17 до 35 лет. Одной из задач исследования является изучение особенностей структуры и уровня тревожности у студентов, работавших в «красной» зоне в период пандемии COVID-19. Проанализированы уровень и структура тревожности. Получены статистически значимые различия (по критерию Стьюдента). Результаты исследования показали, что более уязвимыми в психологическом плане являются студенты, не работавшие в медицинских учреждениях в период пандемии. Поэтому профилактическая работа должна быть направлена на психологическую поддержку студентов, находящихся на самоизоляции, и активную пропаганду выхода студентов на передовую борьбы с эпидемией.
\end{abstract}

Ключевые слова: тревога, страх, изоляция, студенты, депрессия, пандемия, COVID-19. 


\title{
THE STATE OF ANXIETY IN MEDICAL UNIVERSITY STUDENTS WHO WORKED IN THE "RED ZONE" DURING THE COVID-19 PANDEMIC
}

\author{
Magomedova Patimat Yusupovna \\ Kukhmazova Zarina Mameyevna \\ Yuzbekova Aida Arturovna \\ Scientific adviser: Abdullaeva Naida Murtazalievna
}

\begin{abstract}
The covid-19 pandemic has an adverse influence not only on the physical, but also on the psychological health of the population. The article considers the results of a study conducted in April-June 2020 by a survey of medical university students. The selection is consisted of 226 people aged from 17 to 35 years old. One on the objectives of the research is to study the features of the structure and the level of anxiety in students who worked in the «red» zone during the COVID-19 pandemic. The level and structure of anxiety were analyzed. Statistically significant differences were obtained (Student's criteria). The results of the research showed that students who did not work in the medical institutions during the pandemic are more vulnerable psychologically. Therefore preventive work should be aimed at psychological support for students who are in self-isolation and active promotion of students access to the forefront of the fight against the epidemic.
\end{abstract}

Key words: anxiety, fear, isolation, students, depression pandemic, covid-19.

«Ни один великий инквизитор не имеет тех кошмарных орудий пыток, которые находятся в распоряжении тревоги, и ни один шпион не может так удачно выбрать момент для нападения на подозреваемого или не может так искусно расставить западни, как это делает тревога, и ни один самый въедливый судья не может с таким искусством допрашивать обвиняемого, как это умеет тревога, никогда не отпускающая человека от себя, - ни в развлечениях, ни в шуме, ни в работе, ни в игре, ни днем, ни ночью» - это яркое описание тревожности и ее влияния оставил Сорен Кьеркегор [8, с. 107].

Не стоит удивляться тому, что люди всегда стремятся убежать от тревоги. Ведь она болезненна. В век тотальной урбанизации и стремительного внедрения средств массовой информации во все слои жизни человека, 
открытия все новых и новых заболеваний и микробов тревожность имеет тенденцию к усилению, приобретает массовый характер. Борьба с ней становится приоритетом в работе и исследованиях психологов и врачей, так как успех в этом поможет предотвратить многие тяжелые психосоматические реакции у лиц, подвергшихся психологической атаке с любой стороны.

Что такое тревожность? Мы приведем несколько, на наш взгляд наиболее точных, определений. В «Кратком психологическом словаре» приводится: тревога - эмоциональное состояние, возникающее в ситуации неопределенной опасности и проявляющееся в ожидании неблагополучного развития событий [2, с. 407].

Р. С. Немов описывает так: «Тревожность - постоянно или ситуативно проявляемое свойство человека приходить в состояние повышенного беспокойства, испытывать страх и тревогу в специфических социальных ситуациях» $[5$, с. 265$]$.

Различают тревожность ситуативную и личностную. Под личностной тревожностью понимается устойчивая индивидуальная характеристика, отражающая предрасположенность субъекта к тревоге и предрасполагающая наличие у него тенденции воспринимать широкий спектр ситуаций как угрожающие, отвечая на каждую определенной реакцией. Ситуативная (реактивная) тревожность как состояние характеризуется субъективно переживаемыми эмоциями: напряжением, беспокойством, озабоченностью, нервозностью. Тревожность может носить как конструктивный, так и деструктивный характер.

Личностная тревожность конструктивного характера позволяет человеку более ответственно и серьезно подходить к решению возникающих проблем [1, с.76]. Деструктивная личностная тревожность проявляется нарушением высших психических функций, прямо коррелирует с эмоциональными и невротическими срывами и с психосоматическими заболеваниями.

Ситуативная тревожность конструктивного характера побуждает к поиску и конкретизации проблемы и активному исследованию ситуации для определения угрожающего фактора. Деструктивная ситуативная тревожность выражается в агрессии, чрезмерной зависимости, заниженной самооценке, снижении стремления к высоким результатам [6, с.58]. 
Но стоит помнить, что не существует нормальной психологии, присущей всему человечеству, поэтому существует оптимальный индивидуальный уровень полезной тревоги [7, с. 12].

Однако повышенный уровень тревожности является субъективным проявлением неблагополучия личности. А состояние тревоги чаще всего порождает стресс, в активации тревоги основную роль играют факторы когнитивные. Когнитивные оценки опасности, по-видимому, являются первым звеном в возникновении состояния тревоги, а когнитивная переоценка определяет интенсивность таких состояний и их устойчивость во времени. В данном вопросе важно умение различать страх и тревогу.

3.Фрейд, К.Хорни считают, что тревожность есть диффузное опасение, она беспредметна, страх же является реакцией на специальную опасность, вещественную [4 с. 215]. И страх, и тревога - соразмерные реакции на опасность, но в случае страха опасность очевидна и объективна, а в случае беспокойства она субъективна и скрыта [7, с. 47]. Страх и тревога связаны между собой посредством беспокойства, которое является результатом появления у человека страхов. Беспокойство при длительном воздействии устойчиво увеличивает общую тревожность. Сегодня человечество охвачено тотальной пандемией страха, пациенты, пережившие сильный приступ беспокойства, говорят, что предпочли бы лучше умереть, чем испытать это снова.

Основные страхи студентов-медиков основаны на постоянном нахождении в стационаре вдали от семьи, контакте с зараженными (в «красной» зоне) или постоянном ощущении неопределенности и беспокойства, гиподинамии, обилии свободного времени для просмотра средств массовой информации (студенты на самоизоляции).

В нашем исследовании проведен сравнительный анализ уровня тревожности этих групп исследуемых, который покажет, какие студенты оказались наиболее устойчивыми и какие страхи оказались более сильными.

Актуальность. Пандемия Covid-19 на сегодня является самой обсуждаемой темой, врачи всего мира отмечают массовое возникновение деструктивных психических реакций у здоровых людей, среди которых искаженное восприятие реальной ситуации, панические атаки, страх, фобия, тревога, депрессия. А постоянное беспокойство играет определяющую роль в формировании невротического характера [7, с.5]. Исходя из этого, число людей, которым необходим особый медицинский или психологический 
подход, с каждым днем только увеличивается. Поэтому мы нуждаемся в здоровом поколении будущих врачей. А пандемия не обошла стороной и жизнь студентов-медиков.

Цель исследования. Обосновать теоретически и проверить экспериментальным путем методом проведения социологического исследования влияние пандемии на возникновение тревожности у студентов медицинских вузов, работавших и не работавших в «красной» зоне во время пандемии.

Материалы и методы. Для достижения цели нашего исследования использовались следующие методы: анализ литературы, беседа, анкетирование, математико-статистическая обработка данных. Анонимное анкетирование прошли студенты Дагестанского, Астраханского и Сибирского государственных медицинских университетов в возрасте от 17 до 25 лет (средний возраст- 20 лет), всех курсов обучения, лечебного, педиатрического и стоматологического факультетов. Среди респондентов число студентов женского пола составило 168 человек (74,3\%), мужского пола - 53 (25,7\%) человека. Из них 29 студентов, работавших в «красной» зоне в период пандемии, среди которых 62 \% девушки (18 чел.) и 38\% (11 чел.) юноши. 62\% (18 чел.) опрошенных работали в качестве младшей медсестры / медбрата, 24\% (7 чел.) - санитарами, 14\% (4 чел.) - волонтерами. Контакт с респондентами был посредством интернет сети в период ограничительных мep.

Нами была разработана специальная анкета, включавшая следующее: инструкция о заполнении, биометрические показатели (вес, рост), вопросы, оценивающие отношение респондентов к пандемии covid-19, особенности самоизоляции, факт работы в «красной» зоне в период пандемии, длительность работы. Также опросник включал шкалу Спилбергера (StateTrait Anxiety Inventory - STAI) для оценки ситуативной и личностной тревожности (русскоязычная адаптация Ханина).

Шкала включает по 20 вопросов в двух частях (ситуативная и личностная отдельно), для каждой подсчитывается отдельный результат в баллах (диапазон: 20-80 баллов). Показатель ниже 30 баллов - низкая тревожность, 31-44 балла - умеренная тревожность, 45 и более - тревожность повышенная.

Статистическая обработка проводилась в программах «BioStat» (версия 4.03) и Microsoft Excel 2018 методом описательной статистики, достоверность 
разности результатов исследования изучалась при помощи критерия Стьюдента.

Результаты и их обсуждение. Рассмотрим уровень ситуативной и личностной тревожности в каждой группе. В 1-ой группе (у юношей, работавших в «красной» зоне) выявлен наиболее высокий процент лиц с умеренно-выраженной тревожностью, как ситуативной, так и личностной, что составило 72,7\% (8 чел.) и 63,6\% (7 чел.). Во 2-ой группе (у девушек, работавших в «красной» зоне) также выявлен наиболее высокий процент лиц с умеренно-выраженной ситуативной тревожностью: 61.1\% (11 чел.); но в личностной тревожности доля респондентов этой группы с высоковыраженной тревожностью (55.7\%) значительно превалирует над показателем 1-ой группы(27.2\%).

В 39\% случаев участники 3 группы (девушки, не работавшие в «красной» зоне) имели высоко-выраженную ситуативную тревожность, в 70\% высоко-выраженную личностную тревожность, в то время как во 2-ой группе эти показатели составили $16.7 \%$ и $55.7 \%$.

Статистически значимые различия между группами по критерию Стьюдента получены:

- во 2-ой группе выявлено более высокое среднее значение низковыраженной тревожности (и ситуативной, и личностной), чем в 1-ой группе $(\mathrm{p}<0,01)$;

- средний показатель высоко-выраженной личностной тревожности во 2-ой группе ниже, чем в 3-ей $(\mathrm{p}<0,01)$;

- средний показатель низко-выраженной личностной тревожности во 2-ой группе выше, чем в 3-ей $(\mathrm{p}<0,01)$.

Резюмируя выше изложенное, можно заключить, что:

1. Среди анкетированных лиц в 1-ой и 2-ой группах превалирует умеренно-выраженная ситуационная тревога. Показатель личностной умеренно-выраженной тревожности во 2-ой группе ниже, чем в 1-ой, но выше этого показателя в 3 группе.

2. У группы девушек, не работавших в «красной» зоне в период пандемии, выявлено наибольшее значение высоко-выраженной тревожности и ситуативной и личностной (39\% и 70\%).

Данный результат вызвал у нас особый интерес, так как ожидалось получить наибольший процент высоко-выраженной тревожности у студентов, работавших в «красной» зоне. Объяснить довольно низкий показатель высоко- 
выраженной тревожности может классическая методика парадоксальной интенции В. Франкла (1990). Она учит, как бороться со страхом и фобией, которые стали особенно выраженными во время «неинфекционной» эпидемии, охватившей все мировое общество, породившей психологические и психические проблемы и расстройства, ничуть не уступающих в количестве соматическим проявлениям заражения коронавирусом. «Надо идти навстречу предмету своего страха, надо стараться усилить свой страх произвольно, стараться бояться. Это отношение, которое позволяет довольно успешно, как показывает практика, справиться со страхом»- пишет Франкл в своей методике, и наш результат подтверждает это.

Студенты, находившиеся в центре борьбы с пандемией, более приспособленные и напрямую столкнувшиеся со всей сложностью ситуации, по крайней мере, могли объективно оценить эпидемиологическое положение в населенном пункте, более адекватно оценить риск заражения. У них менее выражена тревога, как субъективное ощущение надвигающейся угрозы, так как угроза известна, находится рядом и студент знает, как ее побороть.

По Ю. Л. Ханину тревожность ситуативная - это реакция на опасение потерять что-то значимое - любимого человека, работу, нематериальные или материальные ценности. Многие студенты во время обучения подрабатывали, но из-за карантинных мер лишились этой возможности, что негативно сказалось на их экономическом благосостоянии, а, следовательно, вызывало немало опасений за свое будущее. Студенты же, которые работали в «красной» зоне, получали соответственное денежное поощрение и от медицинских учреждений, и от своих вузов.

\section{Выводы.}

1. Мы считаем, что необходимо привлечь к профилактической работе со студентами психологов и психотерапевтов для разъяснения правил поведения в ситуации всестороннего психологического давления.

2. Также нужно разработать методики психологической борьбы с последствиями длительной самоизоляции.

3. Как демонстрируют результаты исследования, работа на передовой в борьбе с эпидемией положительно сказывается на психологическом состоянии студентов медицинских вузов, поэтому мы можем рекомендовать работу в качестве младшего медицинского персонала и волонтерскую деятельность. Ведь здоровая психика, возможность противостоять пандемии паники укрепляет иммунитет в первую очередь. 


\section{Список литературы}

1. Божович, Л. И. Проблемы формирования личности / под ред. Д. И. Фельдштейна. - М.: Воронеж, 2005. - 352c.

2. Краткий психологический словарь / под ред. А. В. Петровского, М. Г. Ярошевского. М.: Академия, 2007. 432 с.

3. Мэй Р. Смысл тревоги / перевод с английского: М. И. Завалова, А. Ю. Сибуриной. М.: Класс, 2001. 384 с. С. 215-221.

4. Немов Р.С. Психология: Словарь справочник: В 2 ч. - М.: Изд-во ВЛАДОСПРЕСС, 2003. - $352 \mathrm{c.}$

5. Прихожан А. М. Тревожность у детей и подростков: психологическая природа и возрастная динамика. Воронеж: Изд-во НПО МОДЭК, 2000. 304 с.

6. Хорни К. Невротическая личность нашего времени. СПб.: Питер, 2002. $224 \mathrm{c}$.

7. Kierkegaard S. The concept of dread [Электронный pecypc]. / S.Kierkegaard. - Режим доступа: https://archive.org/details/kierkegaardsconc 0000kier_e7p3/page/n175/mode/2up (дата обращения 15.03.2021)

8. https://painmed.ru/wp-content/uploads/2020/03/SHkala-samootsenkiurovnya-trevozhnosti-Spilberga-Hanina.pdf

(С П.Ю. Магомедова, 3.М. Кухмазова, А.А. Юзбекова, 2021 